\title{
PROFIL KEMAMPUAN AWAL MATEMATIS MAHASISWA PENDIDIKAN MATEMATIKA
}

\author{
Marfi Ario \\ Universitas Pasir Pengaraian \\ marfi.ario.92@gmail.com
}

\begin{abstract}
ABSTRAK Salah satu faktor yang mempengaruhi keberhasilan belajar mahasiswa adalah kemampuan awal matematis. Kemampuan awal matematis merupakan pengetahuan yang dimiliki mahasiswa sebelum memasuki perguruan tinggi, yaitu penguasaan materi matematika sekolah khususnya SMP dan SMA. Penelitian ini merupakan penelitian deskriptif untuk mengungkap kemampuan awal matematis mahasiswa. Sampel penelitian berjumlah 40 orang yang merupakan mahasiswa tahun pertama program studi pendidikan matematika. Teknik pengumpulan data menggunakan teknik tes. Instrumen berupa soal isiang singkat tentang materi matematika SMP dan SMA. Data kemampuan awal dianalisis dengan statitik deskriptif yang disajikan dalam bentuk tabel. Hasil penelitian menunjukkan bahwa kemampuan awal matematis mahasiswa pendidikan matematika sangat rendah dengan rata-rata penguasaan $19,55 \%$ dan seluruh mahasiswa memiliki penguasaan dibawah $50 \%$.
\end{abstract}

Kata-kata Kunci: kemampuan awal matematis, materi matematika sekolah, kompetensi profesional guru.

\section{PENDAHULUAN}

Matematika merupakan ilmu yang penting dalam pengembangan ilmu pengetahuan dan teknologi. Banyak ilmu-ilmu lain yang menggunakan matematika. Pentingnya matematika membuat pelajaran ini diajarkan sejak jenjang pendidikan dasar hingga jenjang pendidikan tinggi. Pada jenjang pendidikan tinggi, umumnya matematika dibagi kedalam dua program studi, yaitu matematika dan pendidikan matematika.

Matematika merupakan ilmu yang sulit bagi sebagian siswa ataupun mahasiswa. Hal ini ditandai dengan laporan siswa di tingkat sekolah yang menyatakan bahwa mereka tidak menyukai matematika. Ketidaksukaan ini disebabkan karena mereka sulit memahami materi matematika tersebut. Selain pada siswa, bahkan mahasiswa yang kuliah di jurusan pendidikan matematika juga merasakan kesulitan memahami materi perkuliahan matematika. Hal ini ditunjukkan dari hasil ujian akhir semester mahasiswa yang rendah. Hanya sebagian kecil mahasiswa yang mendapat nilai yang bagus. Pengalaman peneliti mengajar dibeberapa matakuliah matematika juga menunjukkan bahwa pada proses pembelajaran, mahasiswa sulit memahami materi yang diajarkan.

Kesuksesan mahasiswa dalam mempelajari matakuliah matematika di universitas ditentukan oleh banyak faktor. Salah satu faktor tersebut yaitu kemampuan awal 
mahasiswa (Lestari, 2017). Shodikin (2015) menjelaskan bahwa mahasiswa yang memiliki kemampuan awal yang rendah akan lebih sulit dalam memperoleh pengetahuan baru dan mengaitkannya dengan pengetahuan sebelumnya yang ia miliki. Sedangkan mahasiswa yang memiliki kemampuan awal yang tinggi akan cenderung lebih mudah menerima informasi baru dan mengaitkannya dengan informasi yang telah ada sebelumnya.

Kemampuan awal mahasiswa merupakan kemampuan yang dimiliki oleh mahasiswa dari proses belajar sebelumnya. Hal ini senada dengan yang disampaikan oleh Pamungkas, Setiani, \& Pujiastuti (2017) bahwa kemampuan awal merupakan pengetahuan atau pengalaman yang dimiliki sebelumnya oleh mahasiswa untuk membantunya dalam memahami pengetahuan yang baru atau menyelesaikan permasalahan sejenis maupun permasalahan yang baru. Dengan demikian kemampuan awal bagi mahasiswa tingkat pertama adalah pengetahuan mahasiswa tentang materi-materi matematika sekolah, khususnya materi matematika SMP dan SMA.

Pengetahuan mahasiswa tentang materi matematika SMP dan SMA akan sangat membantu mahasiswa dalam memahami pelajaran di tingkat universitas. Kemampuan awal mahasiswa sangat penting untuk memudahkan kegiatan pembelajaran (Hevriansyah \& Megawanti, 2017). Hal ini disebabkan karena matematika merupakan ilmu yang terstruktur dan berjenjang. Materi sebelumnya menjadi syarat untuk memahami materi berikutnya.

Tingkat kemampuan awal mahasiswa akan mempengaruhi sulit atau mudahnya mahasiswa dalam memahami materi berikutnya. Oleh karena itu, penting untuk mengetahui kemampuan awal mahasiswa. Dengan mengetahui kemampuan awal mahasiswa maka dosen dapat memberikan pembelajaran yang sesuai dengan tingkat kemampuan mahasiswa, sehingga proses pembelajaran dapat berjalan efektif. Sebagaimana disampaikan oleh Masril, Razi, Akmam, \& Irvan (2013) bahwa pengetahuan awal penting untuk dapat memberikan dosis pembelajaran yang tepat, tidak terlalu sukar dan tidak terlalu mudah.

Selain sebagai pedoman dalam memberikan dosis pembelajaran, kemampuan awal juga dapat menjadi tolak ukur dalam mengetahui keberhasilan suatu tindakan atau program. Program studi pendidikan matematika merupakan program studi yang mempersiapkan seorang guru matematika. Berdasarkan Undang-undang Nomor 14 Tahun 2005, untuk menjadi guru, seseorang harus memiliki empat kompetensi yaitu kompetensi pedagogik, kepribadian, professional, dan sosial. Permendiknas Nomor 16 Tahun 2007 menyatakan bahwa salah satu kompetensi professional yaitu menguasai materi, struktur, konsep, dan pola pikir keilmuan sesuai mata pelajaran yang diampu. Berdasarkan amanat undang-undang tersebut maka setelah selesai dari program studi pendidikan matematika, mahasiswa seharusnya memiliki kompetensi professional yang salah satunya ditandai dengan penguasaan materi matematika SMP dan SMA. Untuk mengetahui apakah program studi berhasil meningkatkan pengetahuan materi matematika SMP dan SMA bagi mahasiswa maka diperlukan data awal yang menjadi tolak ukur. Data awal tersebut adalah 
kemampuan awal mahasiswa berupa penguasaan materi matematika SMP dan SMA saat mahasiswa berada ditingkat pertama perkuliahan.

Mengukur keberhasilan program studi dalam menumbuhkan atau meningkatkan kemampuan professional mahasiswa penting untuk dilakukan sebagai bahan evaluasi dalam memperbaiki proses pembelajaran maupun kurikulum di program studi. Hal ini didasarkan pada penelitian sebelumnya oleh Ario (2017) diprogram studi yang sama dengan penelitian ini bahwa rata-rata penguasaan materi matematika sekolah (SMP dan SMA) mahasiswa semester VI adalah 22,50\% dengan 94\% mahasiswa memperoleh skor tidak lebih dari 50. Hal ini menimbulkan dugaan apakah sebenarnya proses belajar di program studi selama ini berhasil atau tidak dalam menumbuhkan atau meningkatkan kemampuan matematika sekolah mahasiswa? untuk mengukur hal tersebut maka diperlukan data yang cukup salah satunya data kemampuan awal mahasiswa. Berdasarkan paparan tersebut, maka penelitian ini dilakukan untuk mengetahui kemampuan awal matematis mahasiswa pendidikan matematika tingkat pertama.

\section{METODE PENELITIAN}

Penelitian ini merupakan penelitian deskriptif dengan maksud untuk mendeskripsikan dan menginterpretasikan data kemampuan awal matematis mahasiswa pendidikan matematika Universitas Pasir Pengaraian. Subjek penelitian ini adalah mahasiswa pendidikan matematika semester II tahun pelajaran 2016/2017 yang terdiri dari dua kelas. Kelas Reguler yang terdiri dari 24 mahasiswa dan kelas Non Reguler yang terdiri dari 16 mahasiswa.

Teknik pengumpulan data berupa teknik tes. Instrumen tes berupa soal-soal kemampuan awal matematis yang terdiri dari 20 soal materi SMP dan 20 soal materi SMA. Soal tes yang diberikan merupakan soal isian singkat. Mahasiswa diminta untuk mengisi jawaban akhir saja tanpa menuliskan langkah-langkah penyelesaiannya.

Data nilai kemampuan awal matematis siswa dianalisis menggunakan statistik deskripitif. Data disajikan dalam bentuk tabel untuk memperlihatkan beberapa ukuran statistik dari data seperti rata-rata, simpangan baku, nilai minimal, dan nilai maksimal, serta persebaran nilai mahasiswa. Hasil analisis data kemudian diinterpretasikan untuk memberikan gambaran tentang kemampuan awal matematis mahasiswa pendidikan matematika.

\section{HASIL DAN PEMBAHASAN}

Data kemampuan awal matematis mahasiswa pendidikan matematika diperoleh dari tes tertulis yang berisi 40 soal isian singkat. 20 soal merupakan materi matematika SMP dan 20 soal merupakan materi matematika SMA. Hasil jawaban mahasiswa dari kelas reguler (24 mahasiswa) dan non reguler ( 16 mahasiswa) dinilai dengan skala 0100. Deskripsi data hasil tes kemampuan awal matematis mahasiswa pendidikan matematika disajikan pada Tabel 1 berikut. 
Tabel 1. Skor Kerjasama dan Keaktifan Belajar Mahasiswa pada Siklus I

\begin{tabular}{clccc} 
Ukuran Statistik & \multicolumn{1}{c}{$\begin{array}{c}\text { Jenjang } \\
\text { Sekolah }\end{array}$} & $\begin{array}{c}\text { Kelas } \\
\text { Reguler }\end{array}$ & $\begin{array}{c}\text { Kelas } \\
\text { Non Reguler }\end{array}$ & Gabungan \\
\hline \hline \multirow{2}{*}{ Rata-rata } & SMP & 33,33 & 15,00 & 26,28 \\
\cline { 2 - 5 } & SMA & 15,83 & 8,00 & 12,82 \\
\cline { 2 - 5 } & Gabungan & 24,58 & 11,50 & $\mathbf{1 9 , 5 5}$ \\
\hline \multirow{2}{*}{$\begin{array}{c}\text { Simpangan } \\
\text { Baku }\end{array}$} & SMP & 18,40 & 20,62 & 21,05 \\
\cline { 2 - 5 } & SMA & 11,48 & 8,19 & 11,01 \\
\cline { 2 - 5 } Nilai Minimum & Gabungan & 13,47 & 12,28 & $\mathbf{1 4 , 3 5}$ \\
\cline { 2 - 5 } & SMP & 0,00 & 0,00 & 0,00 \\
\cline { 2 - 5 } & SMA & 0,00 & 0,00 & $\mathbf{0 , 0 0}$ \\
\cline { 2 - 5 } Nabungan & 0,00 & 0,00 & 75,00 \\
\hline \multirow{2}{*}{ Naksimum } & SMP & 65,00 & 75,00 & 40,00 \\
\cline { 2 - 5 } & SMA & 40,00 & 20,00 & $\mathbf{4 7 , 5 0}$
\end{tabular}

Berdasarkan Tabel 1 dapat diketahui bahwa kemampuan awal matematis mahasiswa pendidikan matematika secara keseluruhan adalah 19,55\%. Hasil ini menunjukkan bahwa kemampuan awal matematis mahasiswa sangat rendah. Hal ini tentu akan berpengaruh kepada kesiapan mahasiswa dalam menerima pelajaran matematika di tingkat universitas.

Jika ditinjau dari kelas mahasiswa, mahasiswa dari kelas reguler memiliki kemampuan awal matematis yang lebih baik dibandingkan mahasiswa kelas non reguler. Perbandingan kemampuan awal mahasiswa reguler dan non reguler yaitu $25 \%: 12 \%$. Dilihat dari nilai tertinggi, kelas reguler juga lebih unggul dibanding kelas non reguler. Jika dilihat lebih rinci berdasarkan materi tes kemampuan awal matematis, penguasaan materi matematika jenjang SMP lebih tinggi daripada materi matematika pada jenjang SMA dengan perbandingan penguasaan materi $26 \%$ : 13\%. Artinya materi matematika SMP dikuasai dua kali lipat lebih banyak daripada materi matematika SMA. Hal ini wajar karena materi SMP lebih mudah dibandingkan materi SMA.

Meskipun materi SMP dikuasai lebih banyak oleh mahasiswa dibandingkan materi SMA, tapi hasil penguasaan materi SMP belum bisa dikatakan bagus. Hal ini karena tingkat penguasaan yang masih sangat rendah yaitu $26 \%$. Selain itu juga karena masih ada 7 dari 39 orang mahasiswa yang mendapatkan nilai 0 . Artinya tidak ada satupun soal materi SMP yang bisa dijawab dengan benar oleh 7 mahasiswa tersebut. Pada materi tingkat SMA, penguasaan mahasiswa jauh lebih rendah yaitu $13 \%$. Jumlah mahasiswa yang memperoleh nilai nol lebih banyak yaitu 9 dari 39 orang. Sedangkan secara keseluruhan, ada 4 dari 39 mahasiswa yang memperoleh nilai nol. Artinya, tidak ada satu soal pun dari 40 soal kemampuan awal matematis yang dapat dijawab benar.

Berdasarkan nilai maksimum yang diperoleh, materi SMP dikuasai paling tinggi $75 \%$. Artinya tidak ada satu mahasiswa pun yang mampu menguasai $100 \%$ materi SMP. Untuk materi SMA bahkan jauh lebih rendah lagi, yaitu 40\%. Artinya tidak ada 
mahasiswa yang mampu menguasai separuh dari materi SMA. Sedangkan secara keseluruhan, nilai tertinggi yang diperoleh yaitu 47,50. Hal ini menunjukkan bahwa tidak ada satu mahasiswapun yang mempunyai kemampuan awal lebih dari $50 \%$. Persebaran nilai kemampuan awal matematis yang diperoleh mahasiswa disajikan pada Tabel 2 berikut.

Tabel 2. Persebaran Nilai Tes Kemampuan Awal Matematis

\begin{tabular}{cccc} 
Interval Nilai & \multicolumn{3}{c}{ Frekuensi } \\
\cline { 2 - 4 } & SMP & SMA & Gabungan \\
\hline $0,00-25,00$ & 20 & 35 & 28 \\
\hline $25,01-50,00$ & 15 & 4 & 11 \\
\hline $50,01-75,00$ & 4 & 0 & 0 \\
\hline $75,01-100,00$ & 0 & 0 & 0 \\
\hline
\end{tabular}

Berdasarkan Tabel 2, dapat diketahui bahwa secara keseluruhan, 28 (72\%) mahasiswa memiliki nilai pada rentang $0-25$. Sedangkan sisasnya (28\%) berada pada rentang 25-50. Tidak ada mahasiswa yang memiliki nilai lebih dari 50. Jika dilihat berdasarkan materi tes, ada $4(10 \%)$ mahasiswa yang berada pada rentang nilai $50-$ 75. Sedangkan sisanya (90\%) memiliki nilai dibawah 50. Untuk materi SMA, seluruh mahasiwa nilai dibawah 50. Tabel 2 menunjukkan bahwa kemampuan awal matematis mahasiswa sangat rendah. Seluruh mahasiswa memiliki kemampuan awal matematis yang kurang dari $50 \%$.

Secara umum dapat dikatakan bahwa kemampuan awal matematis mahasiswa pendidikan matematika masih sangat rendah. Rendahnya kemampuan awal matematis ini akan memiliki pengaruh kepada keberhasilan mahasiswa dalam mengikuti perkuliahan matematika. Seseorang yang memiliki kemampuan awal yang baik akan lebih cepat dalam memahami materi dalam proses pembelajaran dibandingkan seseorang yang memiliki kemampuan awal yang tidak baik (Masril dkk., 2013). Hal ini disebabkan karena matematika merupakan ilmu yang berjenjang, yaitu konsep pada materi sebelumnya diperlukan untuk materi berikutnya (Romadiastri, 2012).

\section{KESIMPULAN DAN SARAN}

Kesimpulan yang diperoleh dari penelitian ini yaitu kemampuan awal matematis mahasiswa pendidikan matematika sangat rendah dengan rata-rata tingkat penguasaan yaitu $19,55 \%$. Seluruh mahasiswa memiliki tingkat kemampuan awal matematis di bawah $50 \%$.

Berdasarkan kesimpulan tersebut maka mahasiswa harus berupaya keras untuk mempelajari materi dasar matematika supaya tidak kesulitan dalam mempelajari materi lebih lanjut selama menjalani perkuliahan. Selain itu, kepada dosen pengajar diharapkan mampu pembelajaran yang sesuai dengan tingkat kemampuan awal matematis mahasiswa supaya pembelajaran tetap mampu diikuti dengan baik oleh mahasiswa. 


\section{DAFTAR PUSTAKA}

Ario, M. (2017). Profil penguasaan materi matematika sekolah mahasiswa pendidikan matematika semester VI. AKSIOMA: Jurnal Program Studi Pendidikan Matematika, 6(3), 385-392. https://doi.org/10.24127/ajpm. v6i3.1129

Hevriansyah, P., \& Megawanti, P. (2017). Pengaruh kemampuan awal terhadap hasil belajar matematika. JKPM (Jurnal Kajian Pendidikan Matematika), 2(1), 37-44. https://doi.org/10.30998/jkpm.v2i1.1893

Lestari, W. (2017). Pengaruh kemampuan awal matematika dan motivasi belajar terhadap hasil belajar matematika. Jurnal Analisa, 3(1), 76-84. https://doi.org/10.15575/ja.v3i1.1499

Masril, Razi, P., Akmam, \& Irvan. (2013). Analisis Kemampuan Awal Mahasiswa Tahun Pertama Jurusan Fisika FPMIPA UNP. Diambil dari http://fisika. fmipa.unp.ac.id/wp-content/uploads/ 2014/12/File10.pdf

Pamungkas, A. S., Setiani, Y., \& Pujiastuti, H. (2017). Peranan pengetahuan awal dan self esteem matematis terhadap kemampuan berpikir logis mahasiswa. Kreano, Jurnal Matematika Kreatif-Inovatif, 8(1), 61-68. https://doi.org/10.15294/kreano.v8i1.7866

Permendiknas Nomor 16 Tahun 2007 tentang Standar Kualifikasi Akademik dan Kompetensi Guru.

Romadiastri, Y. (2012). Analisis kesalahan mahasiswa matematika dalam menyelesaikan soal-soal logika. Phenomenon, 2(1), 75-93.

Shodikin, A. (2015). Interaksi kemampuan awal matematis siswa dan pembelajaran dengan strategi abduktif-deduktif terhadap peningkatan kemampuan penalaran dan disposisi matematis siswa. 1 (1), 61-72.

Undang-undang Nomor 14 Tahun 2005 tentang Guru dan Dosen. 